\title{
Identification of Lactobacillus spp. on Basis Morphological, Physiological, and Biochemical Characteristic from Jawa Super Chicken Excreta
}

\author{
Dini Dwi Ludfiani ${ }^{1}$, Widya Asmara ${ }^{2 *}$, Agnesia Endang Tri Hastuti Wahyuni ${ }^{2}$, and Pudji \\ Astuti $^{3}$ \\ ${ }^{1}$ Student in Faculty of Veterinary Medicine, Universitas Gadjah Mada, Yogyakarta, Indonesia \\ ${ }^{2}$ Department of Microbiology, Faculty of Veterinary Medicine, Universitas Gadjah Mada, \\ Yogyakarta, Indonesia \\ ${ }^{3}$ Department of Physiology, Faculty of Veterinary Medicine, Universitas Gadjah Mada, Yogyakarta, \\ Indonesia
}

\begin{abstract}
The use of antibiotic growth promoter as a feed additive for animals in Indonesia has been prohibited and regulated in law, starting from January 1,2018. Alternative replacement for antibiotic was investigated and introduced to farms such as probiotic. The commonly used probiotic was from the genus Lactobacillus, Bifidobacterium, and Bacillus. The aim of this study was to identify the Lactobacillus strains isolates from Jawa Super chicken excreta. Identification was based on the morphological, physiological, and biochemical characteristics. The sample was collected from Jawa Super chicken in Kalasan, Sleman, Yogyakarta. Each sample was diluted in $0.9 \%$ sterile saline and plated on MRS agar containing bromocresol purple. All plates were incubated at $37^{\circ} \mathrm{C}$ under anaerobic condition. Isolates were identified morphology, physiology, and biochemistry based on fermentation of carbohydrate by using Analytical Profile Index (API $50 \mathrm{CHL}$ ). This study showed that isolates belong to 2 categories of fermentation, facultatively heterofermentative and obligately heterofermentative. Not all isolates can grow at $10^{\circ} \mathrm{C}$, but survive to low $\mathrm{pH}$. Based on biochemical analysis isolates identify as L. brevis and L. pentosus. L. brevis and L. pentosus were strains of the Lactobacillus found in the excreta.
\end{abstract}

\section{Introduction}

Antibiotics in the use of non-therapeutic doses or growth promoters have been widely used as feed additives to increase livestock production and control infection in livestock, but now their use has been banned because of the impact of resistance and residues on livestock products [1-3]. Ban the use of antibiotic growth promoter (AGP) as a feed additive for animals in Indonesia has regulated in law and starting from January 1, 2018, and is written in the Law of the Republic of Indonesia Number 18 of 2009 Article 22 and in the Regulation of the Minister of Agriculture of the Republic of Indonesia Number 14 of 2017, part five.

* Corresponding author: wied_as@ugm.ac.id 
One of the alternatives for AGP that can be chosen is probiotics. Probiotics are live microorganisms that can have a beneficial impact on the host by improving the microbiota environment in the digestive tract $[4,5]$. Commonly, probiotics that use in animal feed was lactic acid bacteria (LAB) [6] such as Lactobacillus, Bifidobacteria, and Bacillus sp. [3].

All of LAB basically have the same characteristics, Gram-positive and do not form spores, do not produce catalase enzymes, facultative anaerobes, be able to ferment lactose with the main product being lactic acid, non-pathogenic, safe for consumption to improve human and livestock health [7]. Lactobacillus is acidotolerant, and has a mechanism to inhibit the growth of various pathogenic bacteria (Gram-positive and Gram-negative) and fungi through the production of lactic acid [8]. Lactobacillus probiotics are known several mechanisms to adhere to intestinal epithelial cells. This property is an important criterion for the colonization of Lactobacillus in the gastrointestinal tract [9].

Lactobacillus can be obtained from isolation from various sources such as processed food products (fermented meat and fish, fermented milk, kimchi, pickles), fermented feed such as silage, living organs (digestive tract), and feces or excreta. Isolation of Lactobacillus from feces or excreta can reflect the bacterial groups that are in the digestive tract. This study aimed to identify the Lactobacillus strains isolates from Jawa Super chicken excreta as probiotic candidates.

\section{Materials and Methods}

\subsection{Sampling}

A total of 12 samples of Jawa Super chicken excreta were collected from a farm in Kalasan, Yogyakarta. The samples were immediately brought to the laboratory and being analyzed.

\subsection{Isolation and identification of LAB}

The collected samples were serially diluted in $0.9 \%$ sterile saline and plated on de Man, Rogosa and Sharpe (MRS) agar containing bromocresol purple. Plates were incubated under anaerobic conditions at $37^{\circ} \mathrm{C}$ for $48 \mathrm{~h}$. Individual colonies were randomly selected to purified by streaking on MRS agar, and stored at $-30^{\circ} \mathrm{C}$ for stock in cryo tube containing $10 \%(\mathrm{v} / \mathrm{v})$ skim milk and $20 \%(\mathrm{v} / \mathrm{v})$ glycerol. Isolates were subcultured in MRS broth at $37^{\circ} \mathrm{C}$ for $24 \mathrm{~h}$ for identified morphology, physiology, and biochemical test. Biochemical identification based on fermentation of carbohydrates by using Analitical Profile Index (API 50CHL) [1012].

The effect of temperature on the growth of bacterial was carried out by inoculating bacterial in MRS Broth at $10^{\circ} \mathrm{C}, 35^{\circ} \mathrm{C}, 40^{\circ} \mathrm{C}$. Growth at different $\mathrm{pH}$ was evaluated by inoculating the bacterial strains in MRS broth at $\mathrm{pH} 2,3,4$, and 5. After 24h incubation at $37^{\circ} \mathrm{C}$ the growth of bacterial was expressed as a value of optical density at $620 \mathrm{~nm}$ (O.D.620). The same way is done for the bile salt test $0 \%, 0.05 \%, 0.15 \%$, and $0.3 \%$. Data of pH and bile salt tests were analyzed using RStudio. Analysis of variance (ANOVA) with the Tukey test was done to verify if there is a significant difference $\mathrm{P}<0.05$ in isolates growth at the different conditions tested.

\subsection{Hemolytic activity}

The hemolytic activity was determined by inoculating the culture on blood agar plates and the plates were observed for the formation of any clean ( $\beta$-hemolysis) or greenish $(\alpha-$ 
hemolysis) hemolytic zones, or no such zone ( $\gamma$-hemolysis) around the Lactobacillus colonies [13]

\section{Results and Discussion}

Identification of phenotypic and genotypic are part of the first step in the selection of potential probiotic bacteria. In this study, the results presented were phenotypic identification. From the 12 samples analyzed, only 4 samples were able to be isolated and identified. They are $\mathrm{J} 1, \mathrm{~J} 5, \mathrm{~J} 10$, and $\mathrm{J} 12$. Based on morphologically test, all bacteria isolates were Gram-positive, catalase-negative, homo fermentative, non-motile, and rod shape. The colonies were circle, slightly raised, and white. All bacteria isolates were found to be good acid producers by changing the color of the medium completely from purple to yellow within $48 \mathrm{~h}$ incubation. Similar study was reported by Tilahun [14] group of Lactobacillus and Enterococcus were found to be good acid producers by changing the color of the medium completely from green to yellow within $12 \mathrm{~h}$ of incubation. LAB which produces acid belongs to genera Pediococcus, Lactobacillus, Streptococcus, Leuconostoc, and Bacillus species [15]. The general characteristics of LAB are Gram-positive and do not form spores, almost all strains are unable to produce the enzyme catalase, most isolates are facultatively anaerobic and able to ferment lactose with lactic acid as the main product [16]. The reaction of catalasenegative shows that there is no degradation of $\mathrm{H}_{2} \mathrm{O}_{2}$ to $\mathrm{O}_{2}$ by the catalase enzyme [17].

Table 1. Physiological characterization of four isolates

\begin{tabular}{|l|c|c|c|c|}
\hline \multirow{2}{*}{$\begin{array}{c}\text { Isolate } \\
\text { name }\end{array}$} & \multicolumn{4}{|c|}{ Resistance to acid } \\
\cline { 2 - 5 } & $\mathrm{pH} \mathrm{2}$ & $\mathrm{pH} \mathrm{3}$ & $\mathrm{pH} \mathrm{4}$ & $\mathrm{pH} \mathrm{5}$ \\
\hline $\mathrm{J} 1$ & $0.122 \pm 0.012^{\mathrm{a}}$ & $0.104 \pm 0.020^{\mathrm{b}}$ & $0.105 \pm 0.019^{\mathrm{c}}$ & $0.624 \pm 0.045^{\mathrm{d}}$ \\
\hline $\mathrm{J} 5$ & $0.135 \pm 0.000^{\mathrm{b}}$ & $0.110 \pm 0.010^{\mathrm{b}}$ & $0.111 \pm 0.021^{\mathrm{c}}$ & $0.341 \pm 0.021^{\mathrm{d}}$ \\
\hline $\mathrm{J} 10$ & $0.111 \pm 0.001^{\mathrm{c}}$ & $0.094 \pm 0.008^{\mathrm{b}}$ & $0.112 \pm 0.021^{\mathrm{c}}$ & $0.599 \pm 0.008^{\mathrm{d}}$ \\
\hline $\mathrm{J} 12$ & $0.764 \pm 0.005^{\mathrm{d}}$ & $0.102 \pm 0.037^{\mathrm{b}}$ & $0.103 \pm 0.034^{\mathrm{c}}$ & $0.296 \pm 0.034^{\mathrm{d}}$ \\
\hline \multicolumn{5}{|c|}{ Bile tolerance } \\
\cline { 2 - 5 } & $0 \%$ & $0.05 \%$ & $0.15 \%$ & $0.3 \%$ \\
\hline $\mathrm{J} 1$ & $2.137 \pm 0.002^{\mathrm{a}}$ & $0.402 \pm 0.086^{\mathrm{b}}$ & $0.882 \pm 0.065^{\mathrm{c}}$ & $0.648 \pm 0.078^{\mathrm{d}}$ \\
\hline $\mathrm{J} 5$ & $1.862 \pm 0.053^{\mathrm{b}}$ & $0.553 \pm 0.066^{\mathrm{b}}$ & $1.165 \pm 0.028^{\mathrm{c}}$ & $1.330 \pm 0.044^{\mathrm{d}}$ \\
\hline $\mathrm{J} 10$ & $2.117 \pm 0.084^{\mathrm{c}}$ & $0.525 \pm 0.067^{\mathrm{b}}$ & $0.827 \pm 0.048^{\mathrm{c}}$ & $1.020 \pm 0.030^{\mathrm{d}}$ \\
\hline $\mathrm{J} 12$ & $1.466 \pm 0.058^{\mathrm{d}}$ & $0.565 \pm 0.054^{\mathrm{b}}$ & $1.084 \pm 0.071^{\mathrm{c}}$ & $1.253 \pm 0.088^{\mathrm{d}}$ \\
\hline
\end{tabular}

Results were expressed as a value of O.D. 620. Each value represents the mean value \pm standar deviation $(\mathrm{SD})(\mathrm{n}=4)$. For each isolate, average values $( \pm \mathrm{SD})$ within the same row followed by common superscript letters do not differ significantly $(\mathrm{P}<0.05)$.

From the physiology test, all bacteria isolates were not able to grow at temperatures of $10^{\circ} \mathrm{C}$, and survive under low $\mathrm{pH}$ and bile salt conditions after $24 \mathrm{~h}$ incubation (Table 1 ). The bacteria to be used as probiotics should be able to resist inhibitory factors in the gastrointestinal tract such as gastric juice and bile salts. For this purpose, the effect of different concentrations of acid and bile salts on the growth of bacteria isolates was investigated. Based on Table 1, the growth of the bacteria decreased at $\mathrm{pH} \mathrm{3}$, and the maximum growth was observed at $\mathrm{pH} 5$, and $\mathrm{J} 5$ showed the best tolerance to bile salts.

Thus far, researches have been made to identify potential probiotic LAB isolated from any resources because of their benefits. Stringent selection criteria for selecting highly potent probiotic strain and safety are highly important and should be studied using in vitro and/or in vivo screening methods [9]. Tolerance to acids and bile salts is an important criterion in the selection of potential probiotic. The digestive tract has high acidity in the proventriculus and ventriculus, while the intestine has a high concentration of bile salts, therefore probiotic 
bacteria are expected to be able to maintain their viability and functionality while in the digestive tract [18]. Acid tolerance of bacteria is important for withstanding gastric stresses [9]. Various hydrogen ion concentrations affect the growth of bacteria and suppressed growth. This is because the overall proton permeability of the plasma membrane and mechanism in fermentative bacteria appears to be the proton-translocating ATPase [19]. The lipid components that dominate the membrane of Gram-positive bacteria play an important role in maintaining the membrane structure in reducing cell leakage caused by bile salts [20]. Bile acts an important role in specific and nonspecific defense mechanism of the gut and the effect of inhibitory is determined by the bile salts concentrations. The resistance of bile salt is an important characteristic of LAB to know them to survive, grow and their action in gastrointestinal [21].

Table 2. Identification by API 50CHL

\begin{tabular}{|l|l|r|}
\hline Isolates & \multicolumn{1}{|c|}{ Identification by API 50CHL } & $\%$ \\
\hline J1 & Lactobacillus pentosus & 88,7 \\
\hline J5 & Lactobacillus brevis & 99,1 \\
\hline J10 & Lactobacillus raffinolactis & 54,8 \\
\hline J12 & Lactobacillus pentosus & 99,7 \\
\hline
\end{tabular}

Based on the biochemical test by API 50CHL (Table 2), all isolates were identified as Lactobacillus. The similarity rate above 90\% with Lactobacillus are J5 (99.1\%) and J12 (99.7\%). All isolates could ferment 20 types of carbohydrate, including L-arabinose, ribose, D-xylose, galactose, D-glucose, D-fructose, D-mannose, mannitol, N-acetylglucosamine, amygdalin, arbutin, esculin, salicin, cellobiose, maltose, lactose, melibiose, trehalose, Draffinose, and B-gentibiose.

Hemolytic activity was used to evaluate the safety of probiotic strains [22]. The absence of hemolytic activity is considered safe for the selection of probiotic strains. Hemolysis is a known virulence factor among pathogenic microorganisms [21]. Based on hemolytic activity, all bacteria isolates showed $\gamma$-hemolysis. A similar study was reported by Tallapragada et al. [21] and Maragkoudakis et al. [23] Lactobacillus sp. G3_4_1TO2, L. fermentum, and $L$. paracase $i$ were isolated from dairy products which showed $\gamma$-hemolysis. WHO and FAO recommended the other evaluation for the safety of probiotic starin by antibiotic susceptibility testing. Previous studies [22] reported L. brevis and L. pentosus isolated from duck and Jawa Super chicken excreta showed resistance to Streptomycin.

\section{Conclusion}

The bacteria were successfully isolated from Jawa Super chicken excreta and identified as Lactobacillus using the morphological, physiological, and biochemical tests. The bacteria identity as L. brevis and L. pentosus were confirmed using API 50CHL with a similarity level of $99 \%$. Further studies are needed to adhesion assay, antimicrobial activity, and microbial resistance to complement property for probiotics.

\section{References}

1. A.P. Sinurat, T. Purwadaria, I.A.K. Bintang, P.P. Ketaren, N. Bermawie, M. Raharjo, M. Rizal, JITV-IJAVS 14, 2, 90-96 (2009)

2. Soeripto, Jurnal Litbang Pertanian 21, 2, 48-55 (2002)

3. T. Haryati, WARTAZOA 21, 3, 125-132 (2011) 
4. R. Fuller, Probiotic, 1-8 (1992)

5. I.P. Kompiang, Pengembangan Inovasi Pertanian 2, 3, 177-191 (2009)

6. Mulyono, R. Murwani, F. Wahyono, J. Indon. Trop. Anim. Agric. 34, 2, 145-151 (2009)

7. S.A. Lindawati, IW. Suardana, JVeteriner 17, 4, 576-58 (2016)

8. M. Amin, H. Goodarzi, Z. Orang, S. Farsi, M. Jorfi, Afr. J. Microbiol. Res. 5, 20, 33003304 (2011)

9. C. Wang, P. Lin, C. Ng, Y. Shyu, Anaerobe 16 578-585 (2010)

10. Amaliah, Z.Z.N., S. Bahri, P. Amelia, JFFI 5, 253-257 (2018)

11. P. Thakkar, H.A. Modi, J.B. Prajapati, Int. J. of Cur. Micro. and App. Sci. 4, 4, 713-725 (2015)

12. K. Khedid, M. Faid, A. Mokhtari, A. Soulaymani, A. Zinedine, Microbiological Research 164, 81-91( 2009)

13. D. Halder, M. Mandal, S.S. Chattejee, N.K. Pal, S. Mandal, Biomedicines 5, 31, 1-11 (2017)

14. B. Tilahun, A. Tesfaye, D. Muleta, A. Bahiru, Z. Terefework, G. Wessel, International Journal of Food Science (2018)

15. A. Nigatu, B.A. Gashe, T. Ayele, SINET: Ethiop. J. Sci. 20, 1, 101-114 (1997)

16. Widodo, Bioteknologi Industri Susu 1 (2003)

17. H. Pyar, K.K. Peh, Int. J. Pharm. Sci. 6, 189-193 (2014)

18. A. Menconi, G. Kallapura, J.D. Latorre, M.J. Morgan, N.R. Pumford, B.M. Hargis, G. Tellez, Bioscience of Microbiota, Food, and Health 33, 25-30 (2014)

19. H. Siegumfeldt, K.B. Rechinger, M. Jakobsen, Applied and Enviromental Microbiology 66, 2330-2335 (2000)

20. I.A.S.M. Uni, Y. Ramona, I.N. Sujaya, Archive of Community Health 3, 1, 83-93 (2014)

21. P. Tallapragada, B. Rayavarapu, P.P. Rao, N.N. Ranganath, P.P. Veerabhadrappa, Journal of Genetic Engineering and Biotechnology 16 357-362 (2018)

22. D.D. Ludfiani, W. Asmara, A.E.T.H. Wahyuni, P. Astuti, Vetpract (to be published)

23. P.A. Maragkoudakis, G. Zoumpopoulou, C. Miaris, G. Kalamtzopoulos, B. Pot, E. Tsakalidou, International Dairy Journal 16, 3, 189-199 (2006) 